This item was submitted to Loughborough's Research Repository by the author.

Items in Figshare are protected by copyright, with all rights reserved, unless otherwise indicated.

\title{
New perspectives on design learning, thinking and teaching
}

PLEASE CITE THE PUBLISHED VERSION

http://dx.doi.org/10.1386/adch.12.2.145_2

\section{PUBLISHER}

(c) Intellect

\section{VERSION}

AM (Accepted Manuscript)

\section{PUBLISHER STATEMENT}

This work is made available according to the conditions of the Creative Commons Attribution-NonCommercialNoDerivatives 4.0 International (CC BY-NC-ND 4.0) licence. Full details of this licence are available at: https://creativecommons.org/licenses/by-nc-nd/4.0/

\section{LICENCE}

CC BY-NC-ND 4.0

\section{REPOSITORY RECORD}

Bohemia, Erik, and Peter Lloyd. 2019. "New Perspectives on Design Learning, Thinking and Teaching". figshare. https://hdl.handle.net/2134/18707. 


\section{ADCHE Editorial Special Issue:}

\section{New Perspectives in Design Thinking, Teaching, and Learning}

The articles presented in this special edition of Art, Design, and Communication in Higher Education all derive from the 2nd International Conference on Design Education Research, Design Learning for Tomorrow: Design Education from Kindergarten to PhD, held jointly under the auspices of the Design Research Society and CUMULUS and taking place at the Oslo and Akershus University College of Applied SciencesOslo School of Architecture, Norway in May 2013. The conference featured 165 peer-reviewed paper presentations (from a total of 225 submitted) and provided a state-of-the-art look at research in Design Education at all levels, and across the globe.

Following the conference we selected a number of papers that we considered to be wellargued and well-presented but also gave a sense of new perspectives on research in design education. Each paper in this special issue has gone through a further review process whereby paper authors helped (critically and anonymously) to develop the work of the other authors. We did this to highlight connections between papers but also to ensure that there would be some coherence to the special issue as a whole. Four papers are from the US, with one each from the UK, New Zealand, and Australia.

There were two central themes that determined the selections we made. First, was the idea of using narrative and metaphor, both in teaching and learning. Second, was the idea of design thinking, cutting across both traditional design disciplines and levels of expertise. What also underlies the papers, however, are two further things. First, each displays a deep level of reflection about what is occurring in teaching and learning situations. Perhaps most importantly, though, is the notion of a well-defined and rigorously conducted study about those teaching and learning situations. Indeed, that is what makes these papers examples of design education research.

The special issue begins with Susanna Engbers, who considers the relationship between classical notions of rhetoric and contemporary design practice through the idea of a 'visual text'. Rhetoric, she argues, and particularly the idea of ethos ("how character emerges from language"), forms a fundamental part of designing. She goes on to show how such an idea can be used in the design classroom by explaining how visual texts, for example from Google and BMW, can be deconstructed to reveal the 'nature' of a brand. The paper is an example of how a subject traditionally outside of 'normal' design disciplines, and rarely taught in design schools, can provide considerable insight into the work that designers produce. 
In contrast to Engbers the second paper by Aaron Fry, Jennifer Wilson, and Carol Overby looks at the production (rather than the reception) of images to communicate financial literacy in narrative format. Drawing on key theory about metaphor and different types of thinking, they argue that images can be designed to better communicate emotional and intuitive (as opposed to 'rational') content in helping people to make better financial decisions. This is a timely, and unusual, area of design education research that reveals the wider impact that design can have. They illustrate their theory with an educational case study in narrative visualization.

The first two papers touch on methods of teaching specific skills in design. The third paper, by Elizabeth Boling, Marty Siegel, Kennon Smith, and Patrick Parrish looks at more general aspects of design studio pedagogy, particularly in the attitude or the 'character' that individual design tutors adopt in teaching and learning contexts in the design studio. Through using metaphors and prototypical stories to communicate a teaching 'frame', for example 'stranger rides into the classroom', tutors are able to engage students in a wider narrative of design learning both deepening their experience of design process, and generating dialogue about how design knowledge is acquired.

While Boling et al look at the tutor construction of learning in a design studio, Colin Gray, in the fourth paper, looks at how peer groups construct a set of practices and discourses for more informal aspects of design learning. Gray draws on the concept of habitus - the systematic aspects of the design studio sub-culture in this instance - to study aspects of critique in design education environments. He draws distinctions between the various places where critique occurs (formally and informally) and distinguishes between student beliefs about objective and subjective critique. His study enhances our understanding of the design studio environment as a site of connected spaces where different types of critique - and hence learning =- can occur, and from different types of people.

The fifth paper by Tanya Golja and Lynette Schaverien enriches Grays' account of the design learning habitus by focusing on a first-person account of how knowledge is acquired in architectural education. The first author conducted what she calls a 'learnerresearcher' study in "learning about design by learning to design". The study is a uniquely reflective and rigorous account of the insight and transformation in knowledge that occurred when following a first year course in architectural design, particularly around concepts of quality and value. For example, one of the authors' first-person conclusions is that she:

"came to understand that designing intimately concerned the quality of what was designed, quality that was distilled over time: so designing was not only about a process, about development or reaching a solution. Rather, designing involved 
making explicit why particular choices or decisions were selected as values and realized, and it involved judging quality by testing in the physical and social world." Architectural knowledge is the subject of Demelza Cusens and Hugh Byrd's study of novice and expert architects and it is interesting to reconcile their 'objective' findings about design expertise to the 'subjective' account of the previous paper. Cusens and Byrd compare the results of giving secondary and tertiary students the same architectural design brief of designing a sustainable structure to enhance the skyline of Aukland, New Zealand. The paper reveals (as one would expect) clear differences between the level of sophistication in solution propositions between the two groups of students, but what is interesting (perhaps in the light of Gray's paper) are the critiques of each group on the other groups' work. The study also reveals a baseline level of design thinking in students yet to formally study design.

The final paper in the special issue, by Peter Lloyd and Derek Jones, also draws on an inexperienced set of subjects to explore the nature of creativity in design thinking. They present a conceptualization of design process as a 'grammar of production' which, they argue, allows what they term 'everyday creativity' to find expression. The study they report is of $1038 \mathrm{~T}$-shirt designs produced by first year students pursuing a distance learning course in design thinking. The authors rate these T-shirts on a number of measures and use the way that the results are presented to show how creativity in design can be considered as a normal, everyday phenomenon.

All the papers in the special issue could be said to be attempting to demystify the idea of design and how it might be conceptualised and taught. By focusing on specific aspects of design and design education - rhetoric, narrative, metaphor, expertise, habitus - a more complex, but more understandable and objective, view of contemporary design education emerges; a view that takes varying perspectives - of student, of tutor, of novice, of expert, of naïve inquirer, or critical theorist - in piecing together a richer picture of design education through design education research.

Peter Lloyd

Erik Bohemia

Special Issue Editors 